\title{
LAS TRES VIDAS DE SUCKY (ESCLAVOS Y LIBERTOS EN JEREZ A FINALES DEL ANTIGUO RÉGIMEN).
}

\author{
DOLORES LOZANO SALADO \\ Universidad de Cádiz
}

«Catorce años de guerras le habían enseñado

que no había victoria mayor que la de estar vivo»

(Gabriel García Márquez. El general en su laberinto)

Como señala William D. Phillips Jr., la esclavitud ha sido un rasgo común de la existencia humana, y pocos pueblos del mundo han escapado al sino de ser esclavos, esclavistas o ambas cosas en una u otra época (1). España, a lo largo de su devenir histórico, no ha sido ajena a ninguna de las dos vertientes de la esclavitud (2). Las primitivas comunidades hispánicas, influenciadas por las costumbres de origen de griegos y cartagineses, desarrollaron un intenso empleo del trabajo esclavo. No obstante, fue durante la expansión romana cuando el fenómeno esclavista se consolidó y fijó los modelos que perdurarían en los siglos siguientes tanto en España como en los territorios coloniales. La conquista romana, en sus diferentes etapas, estuvo caracterizada por la esclavización masiva de prisioneros de guerra y por su utilización preferente como fuerza de trabajo en el campo, el artesanado, las obras públicas y las minas. Sólo al final del período Imperial las transformaciones demográficas y económicas alteraron los patrones de empleo de los esclavos y provocaron la decadencia de la institución, que no su desaparición. Primero fueron los esclavos urbanos los que perdieron importancia. Luego les llegó el tumo a los esclavos rurales, que dejaron de ser necesarios. Dió comienzo entonces un proceso de fusión con la baja clase campesina en un nuevo agrupamiento social denominado colonato, de características algo similares a la servidumbre medieval.

Estos cambios continuaron durante la etapa visigoda, pero también persistió la esclavitud, que se mantuvo en los mismos parámetros trazados durante la fase anterior. Los visigodos ya practicaban la esclavitud y comerciaban con ella antes de su contacto con los romanos. Por ello y por su asimilación de las tradiciones y las leyes romanas, los esclavos siguieron siendo en esta época numerosos y las modificaciones implantadas en su estatus, métodos de obtención o usos a que se destinaban fueron variaciones de escasa relevancia. Lo que nunca podrá saberse es si la esclavitud habría emprendido en España la decadencia progresiva que experimentó en el resto de la Europa occidental de no producirse la conquista musulmana, aunque ciertos indicios de declive de la institución en el último período visigodo apuntan que podría haber seguido una evolución similar.

La conquista musulmana supuso, pues, el reforzamiento de la práctica esclavista en Iberia. No sólo en el territorio ocupado, donde los musulmanes incorporaron sus propias leyes y tradiciones. También en los reinos cristianos de 
España y de Portugal, en los que la proximidad del Islam durante siglos permitió que se mantuviera una esclavitud más desarrollada que en muchas otras partes de la Europa medieval.

La esclavitud constituyó un componente importante en la sociedad musulmana medieval. Tres razones contribuyeron a ello. Por un lado, ya era una institución bien asentada en la península arábiga antes del surgimiento del Islam. Por otro, en su rápido proceso de expansión por el Oriente Medio y el África del Norte conquistaron tierras donde la esclavitud también existía. Y en tercer lugar, el Islam como religión, al igual que el judaísmo o el cristianismo, en nada se oponía a la posesión de esclavos. De todas formas, la esclavitud musulmana fue diferente en ciertos aspectos a la de los romanos o a la de los visigodos. En estas sociedades, especialmente en la romana, los esclavos habían sido una parte importante de la fuerza de trabajo; los musulmanes, sin embargo, raras veces los emplearon como tal. Lo usual era su utilización como domésticos, soldados o administrativos. Además, los esclavos, por lo general, estaban bien integrados en la sociedad dominante, y en el caso de los domésticos, bien integrados en la vida familiar.

Por lo que respecta a la España cristiana, la esclavitud subsistió de forma ininterrumpida durante la Reconquista, aunque sólo funcionó de forma restringida. Se distinguió de la romana porque nunca llegó a haber en ninguno de los reinos cristianos nada parecido a una sociedad esclavista y se distinguió, a su vez, de la esclavitud islámica por el escaso número de actividades en las que se usaban esclavos. La explicación está, sin duda, en la ausencia de motivaciones económicas, pues la única razón que mantuvo la práctica esclavista fue la frontera con el Islam y la situación de guerra permanente (que incluía, no hay que olvidarlo, la posibilidad de ser esclavizados con toda legalidad). No en vano los esclavos fueron casi exclusivamente musulmanes, conseguidos como prisioneros de guerra. Únicamente en el siglo XV los mercaderes catalanes y valencianos los adquirieron en los mercados mediterráneos, mientras que los castellanos comenzaron a comprar esclavos africanos negros, llevados a Europa por los portugueses.

En resumen, la esclavitud en la España islámica contribuyó a la permanencia del sistema en toda la península con más vigor que en cualquier otra parte de la Europa cristiana. Y al mismo tiempo proporcionó una importante base para el posterior desarrollo en América, ya que fueron los musulmanes los que introdujeron en España el cultivo de la caña de azúcar y los que generalizaron el abastecimiento de esclavos negros procedentes del Africa subsahariana, aspectos ambos fundamentales en la colonización hispano-portuguesa del Nuevo Mundo. En tal sentido, como afirma W. D. Phillips, «los ibéricos fueron los legatarios de los musulmanes de la España medieval» (3).

Efectivamente, después del descubrimiento y colonización de América, los españoles establecieron la esclavitud en las nuevas posesiones y lo hicieron sobre la base de las tradiciones existentes. Tradiciones recientes, como la 
utilización de esclavos negros en las plantaciones de azúcar, que ya habían practicado con éxito en las Islas Canarias, y tradiciones antiguas, aunque presentes en la España de 1492, como eran las normas legales que regían la esclavitud desde los tiempos romanos, ratificadas en las Siete Partidas de Alfonso X el Sabio. Por las características y envergadura con que se desarrolló, la esclavitud se convirtió en una importante institución económica y social del Imperio hispanoamericano, que se mantuvo prácticamente hasta el final de su propia existencia (4).

La práctica esclavista pervivió también en la Península hasta los decretos que indirectamente le pusieron fin en la primera mitad del siglo XIX. Se trataba, empero, de una actividad minoritaria y con una finalidad casi meramente suntuaria (5), que había tenido más importancia durante los siglos XV y XVI y que fue perdiendo relevancia a lo largo del XVII, hasta quedar reducida en el XVIII a casos y lugares muy contados.

Aunque fenómeno minoritario, la posesión de esclavos era un hecho en la España Moderna y así lo testifican numerosos trabajos de campo (6). La geografía de la esclavitud, a la luz de esos estudios, abarca prácticamente toda España, si bien la intensidad difiere según las zonas. Andalucía y Levante, y por supuesto Canarias, son las regiones donde tuvo mayor implantación, pero la existencia de esclavos también se ha constatado en áreas hasta hace poco inimaginables como el norte o el interior. En relación con ello, Cortés López, que ha llevado a cabo dos investigaciones de ámbito nacional sobre el desarrollo de la esclavitud negra en los siglos XV y XVI respectivamente, advierte de las sorpresas que podría deparar la realización de estudios monográficos sobre esta cuestión en puntos tradicionalmente considerados ajenos a la actividad esclavista (7).

De todos modos, es indiscutible y de sobra conocido que fueron las ciudades y villas del sur andaluz las que alcanzaron mayor protagonismo en la trata de esclavos durante los siglos XV a XVIII. Sin lugar a dudas, y como es obvio, por su papel preeminente en la carrera de Indias (8). De ahí que sean Sevilla y Cádiz, de todas las ciudades andaluzas, las que cuentan con los efectivos esclavos más considerables. En el caso de Cádiz, la presencia de este colectivo pudo ser numerosa aún en el siglo XVIII, lo que corrobora la conexión de dicha práctica con su posición de puerto monopolista del comercio americano (9).

Si Sevilla y Cádiz ocupan un lugar muy destacado en el tráfico de esclavos durante la Edad Moderna, resulta evidente que las ciudades de su entorno geográfico también participaron de forma sobresaliente en la práctica esclavista, sobre todo las poblaciones costeras de la fachada atlántica gaditana, en especial El Puerto de Santa María y Sanlúcar de Barrameda, antepuerto sevillano este último durante los primeros siglos de relaciones comerciales con las colonias americanas y pequeño emporio complementario de Cádiz desde mediados del siglo XVII el primero. Jerez de la Frontera, en la encrucijada de todos estos lugares, tampoco debió mantenerse al margen de la actividad esclavista. No es 
sólo una suposición basada en la lógica, sino una realidad planteada hace ya muchos años por Hipólito Sancho de Sopranis, que allá por 1940 situaba a las tres localidades citadas en pie de igualdad junto con Cádiz en el hecho de una considerable presencia esclava entre sus pobladores (10).

La importancia que tuvo la esclavitud en la villa señorial de Sanlúcar de Barrameda se conoce bien para finales del siglo XV y comienzos del XVI gracias al trabajo monográfico realizado sobre dicha población por Antonio Moreno Ollero (11). En el caso de El Puerto de Santa María, contamos con el estudio de la esclavitud realizado por Juan Jose Iglesias en su también trabajo monográfico sobre la ciudad en el siglo XVIII, aunque para entonces, igual que en los otros lugares donde la actividad esclavista alcanzó altas cotas de desarrollo, la institución se mantenía ya, en palabras del propio autor, como un fenómeno residual (12). En el caso de Jerez, poseemos muy poca información sobre el tema. Por un lado, esa noticia genérica ya mencionada y alguna más concreta, aportada asimismo por Sancho de Sopranis, sobre la existencia de una cofradía de morenos en el siglo XVI que aglutinaba, en defensa de su situación y buscando remedios a alguna de sus necesidades, a los esclavos negros que habían obtenido la libertad de sus dueños (13). Por otro lado, los datos que proporciona Alfonso Franco, igualmente sobre el siglo XV, en su estudio, repetidamente citado, de la esclavitud en Sevilla y su tierra a fines de la Edad Media (14). Datos sobre la presencia en dicha población de mercaderes jerezanos dedicados a la trata, sobre la inclusión de Jerez en la red de ciudades que abastecían los comerciantes genoveses implicados, desde Sevilla, en el negocio esclavista, sobre un esclavo concreto cuyas fechorías se hicieron famosas en la localidad y, finalmente, sobre las fiestas que organizaban los esclavos, los problemas que estas fiestas creaban a las autoridades y las severas medidas que el cabildo municipal jerezano hubo de tomar para contrarrestarlos. Noticias todas que nos hablan de una ciudad con un destacado papel en la actividad esclavista de la época y que han merecido la atención de otros historiadores al realizar trabajos de síntesis sobre el tema (15).

Esta carencia de estudios casi absoluta (y la certeza de que Jerez contó al menos en el siglo XV y primeros tiempos modernos con una importante población esclava) es la que me ha animado a utilizar una documentación que recogí hace ya bastantes años, cuyo análisis y resultados nunca me parecieron susceptibles de ser publicados. Sin embargo, la madurez que dan los años y la experiencia para ver las mismas cosas con distintos ojos y, sobre todo, la comprobación de que permitía llegar a conclusiones nada diferentes a las que establecen otras investigaciones realizadas con una base documental más solvente contribuyeron a decidirme a usar dichos datos.

En efecto, hace ya muchos años realicé un estudio en una parroquia de Jerez de la Frontera sobre la permanencia o no de la práctica esclavista en la ciudad durante el Setecientos y los primeros años del Ochocientos, hasta la progresiva desaparición de la esclavitud durante la década de los treinta. La parroquia en cuestión es la de San Marcos, una de las seis originarias de la primitiva ciudad 
cristiana que forman el recinto intramuros. Este núcleo histórico no tiene grandes dimensiones en comparación con los arrabales que surgieron en el siglo $\mathrm{XV}$ y que se extendieron ampliamente en su derredor durante las centurias siguientes. La collación de San Marcos, por tanto, no comprende un extenso vecindario. Sin embargo, no por ello se ha de pensar que es poco representativa del conjunto de la población, ya que tiene en su haber ciertas peculiaridades que la convierten en una parroquia idónea para los fines requeridos. Y es que, si bien todo el perímetro fortificado era aún en esta época la ciudad por excelencia, San Marcos constituía, a su vez, uno de los barrios más emblemáticos. Tanto por la posición que ocupaba, en conexión con la vía principal del Jerez extramuros, que ya despuntaba como la principal arteria de la ciudad, como por las características de sus pobladores, pues en él residía buena parte de la aristocracia jerezana y de la alta burguesía agrícola y comercial. Ambas circunstancias indican que se trata de un barrio con un nivel socioeconómico muy elevado. Además, otros estudios realizados revelan que es el sector jerezano que presenta una mayor homogeneidad social en su estructura poblacional (16). Todo ello avala la fiabilidad de este distrito para el estudio señalado (17), aunque, evidentemente, una investigación de envergadura requeriría el examen de más parroquias, si no el de toda la ciudad, y el uso complementario de fuentes notariales. No obstante, circunstancias que no viene al caso comentar, condicionaron en su momento el planteamiento de dicho trabajo sobre los fondos documentales exclusivos de esta parroquia.

De todas formas, quizás no sea tan necesario un estudio de grandes dimensiones para el siglo XVIII como para las centurias anteriores, aunque por supuesto nunca estaría de más. Quiero decir con ello que el siglo XVIII está plenamente caracterizado como un período de decadencia de la institución esclavista en nuestro país, incluso en las zonas donde esta actividad se desarrolló más intensamente. Y por tal razón, la constatación o no de esa permanencia y la valoración de su magnitud me parece perfectamente posible a partir de unos datos como los aquí analizados. Al menos, esa impresión transmite su confrontación con la información examinada en las escasas investigaciones realizadas sobre la esclavitud española en ese siglo (18), comparación que iré desgranando oportunamente en las siguientes páginas. Eso sí, lo que no permiten los registros parroquiales es hacer una caracterización tan completa del fenómeno como la que se obtiene de los protocolos notariales.

En resumen, la investigación que presento tiene como finalidad determinar y caracterizar, siquiera aproximadamente, la situación de la práctica esclavista en Jerez de la Frontera durante el siglo XVIII y el primer tercio del XIX, momento este último en el que ya se ha producido la desaparición de hecho de la institución. El estudio se centra en el análisis exhaustivo de todas las partidas de bautismo, matrimonio y defunción generadas en ese tiempo en la parroquia de San Marcos. Como complemento he utilizado documentación notarial de carácter puntual, que me ha permitido reconstruir la trayectoria vital de una de las esclavas encontradas a través de los diversos protocolos originados por sus sucesivas compraventas y por la concesión final de su libertad. 


\section{Los datos de la decadencia}

El corpus documental del trabajo se compone en total de 7.612 registros distribuidos de la siguiente forma: 3.061 de bautismo, 1.090 de matrimonio y 3.461 de defunción (19). En ese importante número de documentos los esclavos y libertos encontrados son treinta y nueve (20), una cifra exigua que sin duda hay que matizar y comparar con otras para que adquiera su justo valor. En principio, matizar algo obvio pero importante: los registros parroquiales no contabilizan la existencia de esclavos sino los momentos cumbres de esas existencias, por lo que no son éstos todos los esclavos que a lo largo del siglo vivieron en el barrio. Además de ellos, debieron existir otros que se bautizaron y casaron en otras iglesias y que murieron en otros lugares. La propia documentación utilizada da pistas en ese sentido (21). En cuanto a cotejar esta cifra con las de otras poblaciones, es ciertamente una tarea complicada, pues ni dispongo de categorías comparables homogéneas (22), ni cuento, en todos los casos, con una información fundamental: el monto poblacional sobre el que se proyectan los datos cuestionados (23).

No obstante, con la prudencia y reservas necesarias, puedo intentar comparar la realidad jerezana con la de los tres lugares comentados a partir de las cifras globales de procedencia notarial existentes en todos los casos. De su confrontación se intuye que Jerez contaba en el siglo XVIII con una población esclava más numerosa que Murcia y que Trujillo y Cáceres, y quizás también más elevada que la de la vecina ciudad portuense. La diferencia es rotunda con la Alta Extremadura, pues sólo son catorce los documentos relacionados con la esclavitud contabilizados en todo el siglo (y la población de base debía ser sensiblemente mayor a la de la parroquia jerezana donde se realiza nuestro estudio). Con Murcia, la relación no está tan clara, pues si bien son setenta y ocho los esclavos encontrados en todo ese tiempo, el método seguido es, sin embargo, de sondeos, aunque, en contrapartida, hay que tener en cuenta que esta ciudad levantina debía tener más habitantes que Jerez, lo que hace pensar también en el mayor predominio de la práctica esclavista en nuestra localidad, pues los treinta y nueve esclavos jerezanos se inscriben en un núcleo de estudio muy pequeño respecto al resto de la población. En el caso de El Puerto, sus efectivos esclavos durante el siglo XVIII debieron ser más considerables que los de Murcia, como muestran las ochenta escrituras localizadas, igualmente por un sistema de catas, por J. J. Iglesias, pero quizás fueron menos numerosos que los de Jerez. Al menos eso se deduce al establecer una correlación con sus respectivos referentes demográficos. $\mathrm{Y}$ no es extraño porque Jerez contaba en su vecindario con una importante presencia nobiliaria (24), uno de los sectores sociales perpetuadores de la institución esclavista en el siglo analizado. De todas formas, no se puede afirmar con rigor esta premisa. Sería necesario realizar otras comparaciones más certeras porque algunos aspectos de las circunstancias de ambas poblaciones siembran dudas al respecto. Por ejemplo, en Jerez, el hecho, ya comentado, de estar estudiando un barrio especialmente indicado para el tema. Aunque, desde luego, no era el único donde la nobleza tenía una especial importancia. En El 
Puerto, que allí existía otro colectivo con particular protagonismo en la tenencia de esclavos: el de los grandes comerciantes y navegantes a Indias. Además, la cifra de cuarenta y cinco esclavos aportada por los Libros de Familias del Catastro de Ensenada evoca una ciudad con más movimiento esclavista que la imaginada con la información notarial. En fin, son conclusiones contradictorias fruto lógico de las fuentes utilizadas, pues ni los registros parroquiales ni los notariales permiten conocer el número total de esclavos y su evolución.

Lo que sí deja totalmente claro la documentación parroquial utilizada es la progresiva decadencia de la institución esclavista en Jerez a lo largo de todo el siglo XVIII, de manera terminante, además, desde 1730. Las partidas referidas a esclavos disminuyen gradualmente entre 1700 y. 1730 (catorce en la primera década, diez en la segunda y ocho en la tercera) y decaen bruscamente entre 1730 y 1740 para continuar así hasta final de la centuria y primeros años de la siguiente, en los que se detecta la última presencia de un esclavo (curiosamente una partida de bautismo de una niña de doce años que se intuye procede de una compra). Desde 1730 hasta 1810 sólo hay una partida por década relativa a esclavos, e incluso no existe ninguna en la de los sesenta y en la de los ochenta.

Esta tendencia, que también la destaca Juan José Iglesias en su estudio de El Puerto (25), se aprecia igualmente si analizamos los datos desde otra perspectiva: el tipo de registros parroquiales en los que aparecen los esclavos. Desde este punto de vista las conclusiones coinciden de forma rotunda. De las treinta y cuatro partidas encontradas, treinta corresponden a defunciones, una a matrimonio y tres a bautizos. Nos hablan por tanto de una actividad que no se renueva ni por la vía de la descendencia de las esclavas (sólo dos casos) ni por la vía de las compras directas (sólo un caso). Aunque sí queda la posibilidad de renovación a través de la adquisición de esclavos procedentes de otras ventas, práctica como veremos muy frecuente, que no quedaría reflejada en las escrituras parroquiales porque los esclavos en cuestión ya estarían bautizados (26).

Estos datos presentan también otra lectura. El hecho de que casi el 85 por 100 de los esclavos registrados hayan sido encontrados en las primeras décadas del siglo pone de manifiesto la sólida implantación de la práctica esclavista en la centuria anterior. Algo que, por otra parte, concuerda perfectamente con la información que tenemos para finales del siglo XV y principios del XVI. Esta elevada presencia de esclavos se aprecia rápidamente con sólo hojear los registros parroquiales del XVII y del XVI. Pero una impresión más certera se obtiene calculando hipotéticamente el número de esclavos que podríamos encontrar en el siglo XVII al cómputo de 14 esclavos por década (que son los que aparecen en los primeros diez años del Setecientos), operación que da como suma la cantidad de 140 esclavos, cuatro veces superior a la resultante en el siglo XVIII y desde luego muy importante teniendo en cuenta que se proyecta sobre un núcleo de población de unos 1.000 habitantes. 
Los esclavos localizados en los registros parroquiales de San Marcos son fundamentalmente de raza negra, aunque sólo se especifica información sobre su origen o etnia en dieciséis de los treinta y cinco casos. La excepción la constituyen dos esclavas de nación turca. No hay una explicación cronológica a su presencia, pues una aparece en 1713 y otra en 1771 , y tampoco los datos ofrecidos por las partidas permiten aproximar las fechas de su adquisición. Esta reflexión está en relación con la posibilidad de que los esclavos turcos fueran más abundantes en esta zona en los inicios de la centuria que en fechas posteriores. En El Puerto de Santa María, en estos primeros años, J.J. Iglesias detecta, incluso, un significativo predominio de estos esclavos respecto a los negros y mulatos. Y no vuelve a encontrarlos a partir de 1720 (27). En Jerez no hay datos suficientes en las dos primeras décadas para confirmarlo o negarlo, aunque da la impresión de que no es así. En tal sentido, me atrevería a apuntar que la omisión de este pormenor tal vez se puede atribuir a la generalización de la esclavitud negra (28). Eso al menos se desprende de un registro de matrimonio entre esclavos, hijos de esclavas a su vez, del año 1713 , en el que se precisa que la madre de la novia es de nación turca y no se alude para nada a la raza o procedencia de la madre del novio, cuyo nombre y propietario se anotan igual que en el caso de la otra mujer.

Con la excepción de las esclavas turcas, en las que se hace mención directa a su origen, lo general, cuando la información sobre este particular sí consta, es la alusión al color de la piel. Las expresiones más frecuentes son «un/a negro/a esclavo/a» o «un esclavo/a de color negro», pero también se emplea en algunas ocasiones la fórmula «de color moreno», que no sabemos con exactitud si indica una aclaración de la piel por la mezcla con blancos o si se usa como sinónimo de negro (29). La mezcla con blancos desde luego está absolutamente demostrada en todos los estudios realizados sobre la esclavitud. $\mathrm{Y}$ en los documentos utilizados también se intuye. En el mismo matrimonio mencionado más arriba o en los bebés bautizados, hijos de esclavas y de padres «no conocidos». En alguna ocasión se emplea, además, el calificativo pardo, que denota más claramente la condición mulata, aunque es cierto que también se usaba para describir a los esclavos berberiscos.

La tenencia de esclavos en Jerez en este siglo se salda, según los registros parroquiales consultados, con una preferencia absoluta por las mujeres, que constituyen el 76 por 100 de todos los casos encontrados (veintiocho esclavas y nueve esclavos, si exceptuamos los dos bebes niñas, en los que es evidente que no hubo elección posible). Una realidad que está en consonancia con la detectada en muchos de los estudios sobre la esclavitud realizados en nuestro país, aunque la presencia mayoritaria de hombres o mujeres difiere según lugares y períodos. En Jerez, en la etapa que examinamos, el motivo fundamental que inclina a los propietarios de esclavos a preferir mujeres radica, sin duda, en la función exclusivamente doméstica que desempeñan. Por supuesto, tampoco les serían extrañas otras razones, repetidamente exhibidas en la bibliografía existente para explicar el más alto precio pagado por las esclavas. Entre estas razones están, primordialmente, que eran consideradas más 
obedientes y sumisas que los esclavos varones así como su papel protagonista en la reproducción, que ofrecía la posibilidad de obtener nuevos esclavos. Otros argumentos también barajados son su mayor rendimiento en el trabajo, su posible utilización como objeto sexual y su mayor longevidad.

Precisamente, sobre el tema de la edad de los esclavos tenemos muy pocos datos. Las partidas de bautismo aportan dicha información, pero no las de matrimonio y defunción, al menos hasta finales del siglo XVIII. Por lo que respecta a las primeras, el acceso al sacramento del bautismo está en relación con la incorporación del esclavo a la comunidad católica que lo acoge, ya sea por la vía de los nacimientos o por la vía de las compras. Estas dos alternativas quedan perfectamente reflejadas en las tres partidas bautismales de San Marcos. En dos casos se trata de bebés de escasos días y en el tercero de una niña de doce años, supongo que recién adquirida, a la que se le administra el bautismo «con condición, por no constar con certeza haberlo antes recibido la bautizada». La edad de acceso al matrimonio, como se ha advertido, resulta imposible de saber, aunque de no ser así tampoco sería concluyente pues no hay más que un caso registrado. Y tampoco es posible conocer la edad de la muerte. En algunas partidas de defunción se habla de «mozos», pero no parece una referencia a la edad, sino al estado civil -en ocasiones se añade «mozos solteros»- o, en todo caso, puede tener una acepción profesional. Veíamos también que a partir de 1800 se incorpora ya información sobre la edad, pero de ese período sólo existe un registro. La finada es una negra liberta de 68 años, lo que está en relación con la longevidad de las mujeres esclavas antes comentada, aunque no deja de ser un caso puntual que para nada permite establecer conclusiones.

En cuanto al análisis del estado civil de los esclavos, disponemos de más noticias que en el tema anterior, pero es un dato que se especifica en muy pocas ocasiones. Concretamente, sólo se señala en nueve de las treinta partidas de defunción encontradas, y en todas ellas, salvo en una de una viuda, los esclavos estaban solteros. El celibato es, sin duda, el estado civil predominante en este colectivo. No sólo porque es el que más aparece cuando la información se consigna, sino porque únicamente hay un registro de matrimonio en el largo período examinado. Además, han de sumarse de las partidas de defunción los casos ya comentados en los que se habla de «mozos», pues casi con total seguridad esta expresión tiene un significado de soltería.

Otros estudios reflejan igualmente la rareza de los casamientos entre esclavos (30), aunque no ocurre así en el Cádiz del siglo XVII, donde los datos indican un elevado índice de matrimonios en este grupo, incluso un número considerable de uniones entre esclavos y libres, sobre todo entre mujeres esclavas y hombres libres (31). Por ello, tal vez en Jerez, en el XVIII, ocurra lo que apuntan S. Aragón y R. Sánchez en su artículo sobre la Alta Extremadura: que el escaso número de esclavos dificulta enormemente la búsqueda de cónyuge (32) porque a pesar de la evidencia contraria del caso gaditano -muy probablemente explicado por sus particulares circunstancias socio-económicasen poblaciones inmersas en unos parámetros sociales más rígidos no debían ser 
comunes los matrimonios entre esclavos y gente de condición libre. Este inconveniente para encontrar pareja puede que esté en la base de las nupcias cuyo registro parroquial tenemos, pues no deja de sorprender la mezcla de razas y culturas que en él se produce. En tal sentido, A. Franco comenta que el cruce entre musulmán y negro no parece ser muy frecuente, y sólo se producía en el Norte de Africa (33). No obstante, en el enlace consignado en la parroquia de San Marcos, las diferentes procedencias étnicas de cada uno de los contrayentes se encontrarían ya muy mediatizadas al haber nacido ambos en territorio español, que es lo que se deduce de la mención de sus respectivas madres, esclavas de los mismos dueños a los que pertenecen ellos. En cualquier caso, como también apuntan los autores extremeños, los señores preferían servidores solteros, siempre a su disposición. El propósito de una boda complicaba demasiado las cosas: con buena lógica, si los esclavos tenían diferentes dueños, una de las partes o las dos debían plantearse la concesión de libertad o la venta. Hay, sin embargo, escasa o nula información sobre estos aspectos en las diversas fuentes utilizables. De ahí que sea una cuestión poco tratada en los estudios de esclavitud. En el matrimonio encontrado en Jerez, si se produjo venta o liberación fue, desde luego, después de celebrado. La partida indica claramente la condición de esclavos de distintos amos.

Para completar este retrato de los esclavos jerezanos del XVIII, resta hablar de su trabajo y de las actividades para las que se les requería y compraba. Al comentar anteriormente la presencia mayoritaria de mujeres entre ellos, la explicábamos en base a su ocupación fundamentalmente doméstica. Es un lugar común en la historiografía sobre el tema (en especial en el Setecientos) (34) y la documentación de la que partimos no hace sino reafirmar esa conclusión obtenida ya en otros trabajos. Cuando en los registros parroquiales se hace alusión a este asunto, se habla de «criadas y criados», de «sirvientes», de «doncellas» (con acepción profesional, no de soltería) y de «cocheros». No obstante, son más las partidas en las que se ignora este aspecto que en las que se especifica, pero interpretamos esta omisión como señal del carácter generalizado de la condición doméstica. Es más, por encima de esa utilidad laboral, lo que prima en estas fechas es realmente el prestigio que implica tener un esclavo, una idea comúnmente aceptada también por los historiadores que se han acercado al conocimiento de la esclavitud en esta época (35).

Estrechamente relacionada con la función suntuaria que básicamente cumplen los esclavos está la tipología social de los propietarios, que, como muestran los diversos estudios realizados, se modifica en esta centuria respecto a las anteriores. $Y$ es que el espectro social de los propietarios de esclavos era bastante más variado en los siglos XV y XVI que en el XVIII. Como señala Alfonso Franco (36), la esclavitud en Andalucía a principios de la Edad Moderna se encontraba muy difundida socialmente. Todos los grupos sociales poseían esclavos, y aunque nobles y eclesiásticos constituían la mejor clientela de los mercaderes especializados en la trata, practicamente la totalidad de los oficios artesanos y de las profesiones del sector terciario contribuían al mantenimiento de la institución. La razón de que así fuera no estaba tanto en una 
mayor accesibilidad económica a la adquisición de un esclavo, que suponía, como en el XVIII, un serio desembolso monetario, sino en el uso que se hacía del mismo, no sólo como objeto de lujo y distinción, también como mano de obra productiva en oficios que nada tenían que ver con los tradicionales empleos vinculados al servicio doméstico. Esta diversidad de propietarios en el siglo XVI es señalada también por Santiago Aragón y Rocío Sánchez en su estudio de Trujillo y Cáceres (37), diversidad que contrasta significativamente con el reducido paisaje social de los propietarios del XVIII, en el que sólo aparecen individuos de los niveles más altos. Ellos lo relacionan con la subida de los precios al existir una menor oferta, pero otros análisis apuntan hacia la pérdida progresiva de interés de una práctica que el paso del tiempo hacía parecer cada vez más caduca (38).

En Jerez no sabemos cómo era la situación en el siglo XVI, pero posiblemente no difería de la que reflejan los trabajos sevillano y extremeño. No obstante, si buscamos más cercanía para establecer comparaciones más ajustadas, la investigación sobre Sanlúcar de Barrameda realizada por Antonio Moreno corrobora igualmente el amplio panorama social de los poseedores de esclavos en esa centuria (39). Lo cierto, en todo caso, es que en Jerez, en el siglo XVIII, los dueños de esclavos pertenecen a los sectores sociales más elevados. Igual ocurre en El Puerto (40). También, ya lo veíamos, en Extremadura (41). Y asimismo en Murcia (42). Es, en definitiva, una característica generalizada de la esclavitud en el período estudiado.

Salvo en una ocasión, el propietario siempre aparece constatado. No en vano la pertenencia a otro es el principal rasgo que define al esclavo. Los apellidos encontrados muestran un amplio abanico de linajes jerezanos: Barrios, Bernal, Cañas, Dávila, Figueroa, Hinojosa, Morla, Padilla, Ponce de León, Priego, Rojas, Román, Spínola, Trujillo, Villavicencio y Zamora (43). Miembros de estas distinguidas familias de la nobleza local son los que aparecen con mayor profusión y los que acaparan la casi totalidad de los esclavos. Algunos, como don Bruno de Villavicencio, el Marqués de Casa Villavicencio y don Lorenzo Figueroa Ponce de León, están registrados en más de una ocasión por el fallecimiento de sus esclavos, a veces con muy poco tiempo de diferencia entre una fecha y otra, lo que señala que era habitual, al menos durante la primera mitad del siglo, la posesión de varios esclavos simultáneamente. Entre los otros propietarios cuya posible pertenencia a la nobleza ignoro se encuentran profesionales liberales (un médico y un abogado de los Reales Consejos) y apellidos extranjeros probablemente relacionados con la burguesía comerciante (Colarte, Bertenini, Fleiz), aunque la actividad profesional sólo se especifica en los dos casos antes citados. Quizás esta misma aclaración laboral permita deducir que los restantes dueños de esclavos vivían fundamentalmente de las rentas, como lo hacía en general el estamento nobiliario. Hay apellidos, no obstante, cuya adscripción social o profesional desconozco (Argüelles, Guijarro, Neves, Trigueros), pero todos tienen tratamiento de don, lo que ya de por sí indica una condición destacada por encima de la del vecindario (44). 
No parece haber, por tanto, ningún representante del sector artesanal o de profesiones afines en la escala social, aunque muchos de ellos, al menos en los comienzos del siglo XIX, recibían trato de don. Sin embargo, pienso que se hubiese hecho constar, igual que se especifica el carácter de médico o de abogado en otros casos. De cualquier manera, como ya se ha dicho, los artesanos tienen en el siglo XVIII una escasa representación entre los propietarios de esclavos. En ello, aparte de la subida de los precios que apuntan algunos autores, influirían también, según Gonzalo Anes, las trabas y limitaciones impuestas por los gremios a los individuos de color (45).

Tampoco se refleja la existencia de eclesiásticos, a pesar de que este grupo social sigue formando parte en el Setecientos del reducido círculo que mantiene la tenencia de esclavos. Los estudios de El Puerto, de Murcia y de la Alta Extremadura así lo confirman (46). En el caso de Jerez, las razones de su inexistencia tal vez radiquen en las características del barrio analizado, pues no era en él donde residía el alto clero de la ciudad, que vivía preferentemente en la collación del Salvador, donde se hallaba enclavado el templo principal. Con todo, si como es muy probable la distribución socio-urbana de Jerez de principios del siglo XIX conserva los rasgos generales de décadas pasadas, el distrito de San Marcos debía contar entre sus vecinos, en el siglo XVIII, con un buen número de clérigos de cierta relevancia social, ya que en 1818 encontramos en él ocho presbíteros, la mayoría con beneficios eclesiásticos y propiedades urbanas y rústicas. Por ello y porque los diferentes trabajos consultados, tanto del siglo XVIII como anteriores, muestran un amplio espectro de niveles jerárquicos entre los clérigos poseedores de esclavos, no resulta fácilmente explicable su total ausencia en los datos manejados (47).

En resumen, la propiedad de esclavos en el siglo XVIII en Jerez se salda, al menos en el barrio estudiado, con una presencia mayoritaria y casi exclusiva del sector nobiliario, y con una presencia complementaria, quizás, de los niveles más altos del estado llano. A medida que avanza la centuria la posesión de esclavos es una práctica que se reduce únicamente a la nobleza. Tal vez, también, a los miembros de este estamento vinculados de alguna manera a los territorios coloniales americanos. Ésta es una idea que apuntan otros historiadores (48), y en el caso particular de Jerez parece confirmarse igualmente: el último propietario encontrado, ya en el siglo XIX y precisamente a través del bautizo de una niña esclava de doce años cuya reciente adquisición resulta evidente, reúne tales características. Se trata de don Francisco Dávila Guzmán, miembro de un rancio linaje de la ciudad que posee el marquesado de Villamarta. Él no detenta el título, si bien en los padrones municipales se le califica de «hijosdalgo notorio» (49). En 1803, fecha en la que se realiza el bautizo de la referida esclava, debía tener algo más de treinta años, estaba casado con una dama de la nobleza local, doña Melchora Viaña, y era marino de la Real Armada, de donde se retiraría (en 1815 ya lo estaba) con el grado de teniente de navío. Debía disfrutar una situación económica ciertamente desahogada, pero no poseía importantes bienes porque el grueso del patrimonio familiar lo había heredado su hermano primogénito. Tan sólo la casa donde vivía y una viña de 16 
aranzadas, que tras su temprana jubilación le permitiría encauzar hábilmente sus pasos hacia el comercio de vinos. Sus relaciones con América las suponemos por su carrera militar, pues prácticamente todos los marinos, especialmente los altos cargos, llevaban a cabo a lo largo de su vida profesional diferentes servicios en las colonias (50). Es el caso de su hijo mayor, que en 1818 , con 19 años y teniente de infantería, estaba «ausente en Méjico». La esclava adquirida en 1803 debe tener, pues, ese origen. Y su compra, aparte de por las consabidas razones de prestigio y distinción, debía estar enfocada a cubrir el cuidado de los hijos del matrimonio, que eran muchos y pequeños, como indican los datos del padrón de 1818 (seis; el mayor, como hemos visto, de 19 años) (51). En esta fuente, sin embargo, no aparece registrada la esclava, tal vez porque murió, porque fue nuevamente vendida o, con suerte, como apunta $R$. Solís, liberada.

Esta idea me permite enlazar con un último aspecto. La concesión de libertad a los esclavos era, como muestran todos los estudios de las diferentes épocas, una práctica bastante común. Probablemente más habitual en el siglo XVIII, puesto que la esclavitud era ya un fenómeno social en decadencia. J. J. Iglesias, por ejemplo, en su investigación sobre El Puerto de Santa María, encuentra en su recorrido por los protocolos notariales de la centuria cuarenta y cuatro manumisiones frente a veintidós contratos de compraventa o poderes para vender (52). También $R$. Solís comentaba la frecuencia de esta costumbre en Cádiz. Y en otra de sus obras, refiriéndose a los primeros años del XIX, señala que «el libertar esclavos era de buen tono» y acompaña esta manifestación de sendos poemas encontrados en el Diario Mercantil, en los que se enaltecía a los dueños de unos esclavos por el acto de concederles la libertad (53).

Sin embargo, en la investigación que he realizado sobre los registros parroquiales de San Marcos tan sólo he hallado la partida de defunción de una liberta. Una inexistencia prácticamente absoluta que se contradice con la realidad observada en las poblaciones del entorno, realidad extensible a la de los restantes lugares estudiados en el siglo XVIII. Creo, de todos modos, que puede haber varias explicaciones: por un lado, el tipo de fuente analizada, que sin duda noes la más adecuada; por otro, la probabilidad de que los esclavos, al conseguir la libertad, marcharan a vivir a otra parte, bien fuera de Jerez (a las poblaciones de la bahía, por ejemplo, presumiblemente con mayor número de población negra y también con una sociedad menos conservadora) o dentro mismo, a otros barrios con niveles socioeconómicos afines; una tercera posibilidad podría radicar, también, en una mayor magnanimidad de las clases burguesas frente a la nobleza a la hora de liberar a sus esclavos, o, visto de otra manera, en el establecimiento de diferentes relaciones por parte del estamento nobiliario, más arraigadas en el servicio y el acompañamiento de por vida. La segunda hipótesis, quizás la más acertada; la avalan, a su vez, dos argumentos: uno, ya apuntado con anterioridad en relación con otra cuestión: que los esclavos encontrados en las partidas de bautismo y matrimonio no aparecen luego en las de defunción; otro, que la liberta encontrada a través del registro de su fallecimiento procedía, como tendremos ocasión de ver, de la cercana ciudad de Cádiz. 
Pero lo que me interesa verdaderamente es la historia de esta mujer, cuya vida y avatares he podido reconstruir a través de los protocolos notariales gaditanos y de los padrones municipales de Jerez. Su trayectoria vital rescata del anonimato a todos los esclavos aquí estudiados y reviste de autenticidad los fríos datos estadísticos coincidentes en todos los trabajos. Nos permite, además, adentrarnos en los aspectos más privados de la existencia de estos seres, entrever sus condiciones de vida, sentir más de cerca su falta de libertad, la dependencia absoluta de sus amos o la carencia de afectos durante toda una vida. Todo ello, desde luego, muy precariamente, porque las fuentes, aunque centradas en una sola persona, no dejan de ser parcas y esterotipadas.

\section{Vida y muerte de una esclava llamada Sucky}

La protagonista de esta historia con nombre propio se llama María Josefa, pero también Dominga y Sucky, aunque hay razones para pensar que ella prefería ser llamada Dominga. Murió en Jerez, a la edad de sesenta y ocho años, el día 21 junio de 1828 (54). Su partida de defunción ponía tras la pista de su último propietario y del momento, lugar y notario ante el que se le otorgó la libertad. Esta información permitía seguirle el rastro en Cádiz en el año 1798 (55). En esta fecha, el 2 de enero concretamente, Dominga iniciaba una nueva vida como mujer libre tras más de dos décadas de esclavitud repartidas entre seis amos diferentes. Don Juan Antonio Carazo de la Peña, su sexto dueño, vecino de Cádiz y comerciante por más señas, había decidido concederle la libertad tras dos años y medio de mantenerla a su servicio. Según la escritura, que es bastante escueta en detalles, Dominga contaba entonces treinta y seis años (56). Tenía, pues, una larga vida por delante, aunque ella, lógicamente, no lo sabía.

De esta vida futura conozco poca cosa. Sólo he podido reproducir sus últimos años y tampoco completamente. Sí he podido recuperar su pasado desde su llegada a Cádiz en 1777 (57). Es aquí cuando Dominga se convierte en Sucky. Porque éste era su verdadero nombre, quizás no el que le pusieron sus padres, pero sí con el que la denominaron en Inglaterra, el lugar de donde vino. Sucky, que es como aparece escrito en el protocolo notarial, debe estar relacionado con la palabra inglesa sucket, que significa confite, o más probablemente con sucker, que tiene la acepción de 'pimpollo'. Podemos imaginar, por tanto, que nuestra esclava era una chica bonita y atractiva. No obstante, la descripción que de ella hace el notario no deja entrever demasiado este punto. Así, a Sucky, que tenía entonces «dieciséis o diecisiete años poco más o menos», se le retrata como «de color cocho, regular estatura, pecosa de viruelas, nariz chata, con un lunar en la sien derecha y otro más abajo, y un diente menos en la parte de arriba». Estas características, en efecto, no nos dicen gran cosa sobre su aspecto físico. Las restantes compraventas tampoco lo definen mucho más, ya que repiten mecánicamente los mismos detalles (58). Sólo la noticia sobre su color aporta un dato interesante, pues indica que tenía una tonalidad de piel más clara que una negra pura y que era, en consecuencia, el fruto de una unión entre negra y blanco o viceversa. 
Sucky debió ser, por otra parte, una esclava deseada. Su primer amo en Cádiz, don Tomás Juan Arriete, un comerciante de origen ceutí sobre cuya profesión, estado civil y otros datos personales no hay información alguna en la escritura (59), la mandó comprar en Londres a su amigo don Lorenzo Strange, de quien sí se señala que era «del comercio de esta ciudad de Cádiz». El encargo particular de don Tomás, según relata don Lorenzo, era que adquiriese en su nombre «una negra esclava». Lo que no relata el comisionado son las restantes indicaciones que debió darle, pero son presumibles si pensamos en la edad de la muchacha, en el matiz de su piel y en su denominación. Arriete pagó por ella la sustanciosa cantidad de 230 pesos de a 8 reales de plata antigua cada uno (4.600 reales), un valor bastante elevado que la esclava no conseguirá en ninguna de sus restantes ventas. La chica, desarraigada de los suyos, hizo su viaje a España en un navío inglés nombrado La Esperanza.

Sucky permaneció en poder de don Tomás Arriete desde noviembre de 1777 hasta mayo de 1783. En este período, aparte de aclimatarse a un nuevo país, una nueva religión y un nuevo dueño, hubo de afrontar dos hechos muy importantes en su vida: un cambio de identidad y el nacimiento de una hija, probablemente la única ocasión en que fue madre. El apelativo Sucky se lo sustituyeron por el nombre de María Josefa. Esta nueva designación se habría producido en el momento de su bautizo, que sin duda, aunque no hay referencias a él, habría tenido lugar en los primeros tiempos de su llegada (60). En cuanto a su hija, nació el 27 de abril de 1783 y fue nombrada María Dolores. Sólo quince días después de este trascendental acontecimiento ambas eran vendidas a don José Antonio de Huertas, también vecino de la ciudad y alférez de las milicias urbanas de la plaza (61). Las razones por las que don Tomás se desprende de ellas no se explican. Probablemente Sucky ya había cumplido su cometido y con una hija se convertía en una presencia incómoda. Una niña que, como describe el escribano, era «de color pardo», o sea, de piel más blanca que su madre. Además, en los casi seis años transcurridos la situación personal de don Tomás probablemente había cambiado de signo. La venta inmediata al alumbramiento hace pensar que tenía prisa en deshacerse de ellas ( $\mathrm{y}$ antes no la habría podido vender porque nadie se arriesgaría a comprarla embarazada).

Don José Antonio de Huertas pagó por las dos esclavas 160 pesos de a quince reales de vellón cada uno, pero no las tuvo en su poder ni siquiera un año. El 15 de abril de 1784 cumplimentaba ante notario su venta a don Francisco Martí, un comerciante valenciano afincado en Cádiz (62). No obstante, la venta sólo concierne a María Josefa. De la hija únicamente se comenta que fue adquirida junto a su madre en la compra a don Tomás de Arriete. Pero no se menciona si ha muerto o si el dueño ha decidido quedársela o venderla por separado. No eran comunes, sin embargo, dichos extremos; la historiografía de la esclavitud coincide siempre en esta cuestión. Tampoco se argumentan los motivos de la transacción.

María Josefa pasó con don Francisco Martí el mayor período de su esclavitud. Ocho años que concluyeron el 6 de agosto de 1792 con una nueva 
venta a don Juan Antonio Imbrecher, que a su vez la volvió a vender año y medio más tarde (el 4 de enero de 1794) a doña Manuela Danglada (63). Esta señora, residente como los anteriores propietarios en la ciudad de Cádiz (64), la tuvo en su poder menos tiempo que cualquiera de ellos y el 22 de junio de 1795 la entregó a don Juan Antonio Carazo de la Peña por 140 pesos de a 15 reales de vellón cada uno (2.100 reales) (65), la misma cantidad pagada en la tercera operación, lo que hace suponer que fue igualmente la desembolsada en la cuarta y en la quinta. Con la excepción del elevado primer coste, que incluía gastos de viaje, María Josefa mantuvo en sus cinco ventas posteriores el mismo valor (cuando fue vendida junto a su hija la cifra subió en 300 reales), un alto precio también que permite atribuirle unas cualidades físicas y una capacidad laboral importantes (66).

Don Juan Antonio Carazo de la Peña, natural de Cádiz y también un hombre del comercio con las colonias (67), fue el último propietario de María Josefa (68). Su dependencia de este hombre duró, como ya se ha dicho, aproximadamente treinta meses. El segundo día de 1798, tras veintiún años de esclavitud en tierras gaditanas y con la misma condición probablemente en su vida anterior, María Josefa se convirtió en una mujer libre. Pero la escritura de ahorría no aporta información ni de los móviles que condujeron a su amo a redimirla ni del futuro inmediato que esperaba a la nueva liberta (69).

Ignoro, por tanto, si María Josefa continuó viviendo en el hogar de su último dueño en calidad de criada libre como ocurría con frecuencia en las manumisiones de hembras esclavas. Si fue así, su estancia en dicha casa no se prolongó el resto de su vida, como demuestra la reconstrucción de sus últimos años. También parece evidente que don Juan Antonio Carazo no la favoreció con ningún tipo de ayuda económica o material al concederle la libertad. En tal caso, se hubiese hecho constar en el documento notarial. Además, por lo que se aprecia en los diferentes estudios sobre la esclavitud, los ahorramientos que incluyen una recompensa económica se suelen producir tras servicios prolongados en los que se han creado determinados lazos de afecto entre los propietarios, generalmente mujeres, y sus esclavos, igualmente de sexo femenino. Y no es el caso que tenemos entre manos. Más bien parece que el último propietario de Josefa la liberó porque ésta enfilaba una edad y quizás unas condiciones físicas menos óptimas para su mantenimiento en su casa o para una posible nueva venta. Era común en estos tiempos y ya en los anteriores la concesión de la independencia a los esclavos al alcanzar determinada edad. Y la de Josefa cuando la obtuvo, 36 años, estaba en el horizonte de dicho límite.

Lo cierto es que María Josefa vivió, desde este momento, treinta años más en libertad. Su muerte se produjo en Jerez en 1828. Desconozco cuáles fueron sus derroteros entre 1798 y 1818 . Este último año la vuelvo a encontrar, ya instalada en el mismo Jerez que la verá morir, trabajando como criada para doña Isabel Hinojosa, una señora noble, hacendada, de edad dudosa y soltera, con la que comparte también su morada (70). María Josefa ha cambiado su nombre por el de Dominga. No sé por qué, pero sí estoy segura de que se trata de la misma 
persona. Para comprender este convencimiento es necesario advertir que en su partida de defunción aparece como María Josefa Dominga y sin apellidos, como es habitual en los esclavos y libertos. Sin embargo, el segundo nombre no consta en ninguna ocasión en las diversas escrituras de compraventa y libertad. Tal vez se lo impusieron también al bautizarla. Pero es más probable que lo adoptara ella misma cuando comenzó a vivir en libertad: nuevamente un cambio de identidad para una nueva situación. En esta ocasión, voluntario. Prueba de ello es que este nombre es el único que da a los peritos que realizaron el padrón vecinal.

Los datos del vecindario registran otra noticia sorprendente: Dominga aparece con estado civil 'casada', aunque no hay referencias al marido y, desde luego, queda clarísimo que en la casa donde se les ubica solamente viven ella y su señora. La información es extraña, no sólo por las características del contexto, en el que no hay alusión alguna al paradero del esposo -en otros casos viene «ausente»- $o$ a la relación entre ambos -me refiero a los típicos comentarios al margen de «malcasada» o «separada»-, sino también porque en la partida de defunción se indica que era soltera. Esta contradicción entre ambas fuentes es la única que no puedo explicar salvo con especulaciones. Dentro de ellas está el pensar que Dominga mintió. No sabemos cómo pesaba sobre ella su condición real de mujer no doncella, aunque según Isidoro Porquicho en el grupo esclavo el concepto de honestidad de la mujer prácticamente era inexistente (71). La época de esclavitud quedaba, sin embargo, algo lejana. Y estaba en otra ciudad, donde poco o nada se sabría de su pasado. Incluso es posible que su ama tuviera también algo importante que ocultar, pero ésta es otra historia que más adelante retomaré y que quizás ayude a interpretar la presencia de Dominga en Jerez. Igualmente, al campo de las especulaciones corresponde el considerar que verdaderamente se hubiera casado -de ser así, casi con toda seguridad en Cádiz o en El Puerto- y a partir de ahí tenemos varios caminos: uno, que la dependencia como criados de una misma familia dividida en varias ramas les hubiera separado provisionalmente; otro, más probable, que el matrimonio hubiera fallado y cada uno hubiera tirado por su lado. En este caso, por las mismas razones que antes, ella no tendría que dar explicaciones en una ciudad donde era una extranjera. Lo que sí tengo claro es que no es un error del padrón, ya que en el de 1819 se indica el mismo estado civil y, en cambio, varía la edad -41 años, uno menos de los que se le adjudican en el padrón de 1818- y el lugar de origen -El Puerto, mientras que en el anterior registro se apuntaba que era natural de Jerez-.

A estos últimos aspectos no hay que prestar demasiada consideración. La edad en estas fechas es una cuestión, como se ha podido ver en el caso de Isabel Hinojosa, bastante elástica. No es la única vez que lo compruebo. He trabajado mucho con padrones municipales y es un asunto que pocas veces coincide en los distintos documentos examinados. En el caso de Dominga, el problema no radica en unos años más o en unos años menos. La diferencia con su edad real, que aparece correctamente en el acta de defunción, es de diecisiete años. Sin duda ella la desconocía (era algo común en la gente que no sabía leer). Y, probablemente también, a imitación de su señora, recortaría un poco la que creía 
tener. Al morir, la gente de su entorno aportaría al párroco de San Marcos su carta de libertad y demás documentación, de donde extraería, entre otras, la información sobre su edad. Paradójicamente, los años que dice tener Dominga en 1818 concuerdan con los que realmente tendría si su vida hubiera comenzado en 1777, el año en que llegó a Cádiz.

Tampoco tiene ninguna fiabilidad el dato sobre su naturaleza jerezana. El lugar de origen es una variable nueva en los padrones xericienses de principios del XIX y no siempre se cumplimenta con rigurosidad. Como muestra un botón: Isabel Hinojosa aparece en este padrón, en el de 1819 y en uno anterior de 1813 como natural de Jerez; sin embargo, en otro de 1824 se anota que es oriunda de Córdoba. Por supuesto, algo de verdad hay siempre en el trasfondo. En el caso de Isabel, pudo nacer en Jerez o en Córdoba, pero lo que está claro es que alguna vez vivió en la ciudad de la mezquita. En el caso de Dominga, la referencia a Jerez se explica sin problemas porque es la que le ponen a su señora. Pero donde hay algo de cierto es en el origen portuense que se le atribuye en el padrón de 1819 y que solamente significa que residió en El Puerto antes de establecerse en Jerez.

En esta vecina ciudad Dominga pudo haber entrado en contacto con los Hinojosa, aunque dicha relación también pudo surgir en Cádiz. Esta familia constituye uno de los linajes más antiguos de Jerez. Según cuenta Diego Parada, su presencia en la población data de los mismos tiempos de la reconquista, fecha en la que el primer ascendiente obtuvo de Alfonso $\mathrm{X}$ repartimiento en la collación de San Marcos (72). Aquí, en la calle Francos, número 85, se mantiene a principios del siglo XIX la casa solariega de los Hinojosa, que es la misma mansión donde vive Isabel con su criada Dominga. También explica Parada que los miembros de este clan fueron siempre caballeros principales de la ciudad y que destacaron tanto por su relevancia social como por su opulencia económica. Sin embargo, en el Jerez de comienzos del XIX la posición de los Hinojosa no debía ser ya la que fue. Quizás únicamente porque los diferentes integrantes de la familia se habían ido instalando en otras poblaciones. De hecho, la única Hinojosa que vive en estas fechas en la ciudad es Isabel. Y puede ser accidentalmente.

En efecto, he seguido el rastro a los habitantes de la casa de la calle Francos desde 1792 hasta 1828 (73) y el conjunto de información obtenida confirma que esta familia debía haber fijado su domicilio en otro/s lugar/es, ya que sólo intermitentemente aparecen viviendo en ella algunos componentes del clan. Así, en los primeros padrones de 1792 y 1804 se encuentra residiendo en ella el que hay que suponer patriarca de la familia en aquellos momentos, don Agustín Hinojosa y Adorno. Este señor, que en 1792 ya estaba viudo, vivía acompañado en esa fecha por don José Hinojosa y Abril, casado y sin descendencia, del que no se especifica su parentesco con Agustín. Tal vez fuera su hijo, como pienso que lo era Isabel, quien también probablemente vivía en dicha casa, aunque su presencia no se puede confirmar porque se trata de un padrón en el que no se registran las mujeres que no son cabeza de familia. Tampoco se recogen en el de 
1804, vecindario en el que ya no está anotado don José Hinojosa. En el siguiente padrón de 1806 la casa está ocupada por un inquilino ajeno a la familia, lo que permite deducir que don Agustín había fallecido y que el resto del grupo residía en otra/s ciudad/es (74). En el de 1813 aparece por primera vez Isabel. Tiene 34 años, está soltera y vive con una criada de 50 años; también célibe, llamada Catalina de Soto. Además, figura como «agregado» un niño de año y medio de nombre don Agustín Gutiérrez (75). En los siguientes padrones de 1818 y 1819 , Isabel, como ya se vió, continúa viviendo en la casa familiar, ahora con Dominga como criada y seguramente con el niño Agustín, ausente en esas fechas o bien ignorado porque estos censos no siempre incluyen a los más pequeños de edad. La suposición se basa, no obstante, en otra comprobación posterior, de 1824, fecha en la que Agustín, de 13 años entonces, se registra nuevamente junto a Isabel, en esta ocasión sin especificar parentesco ni condición de «agregado». En 1824, sin embargo, ya no viven en la casa solariega de Francos, sino en otra de la calle San José, en el mismo barrio de San Marcos. La secular morada de los Hinojosa la habita en calidad de arrendatario un importante bodeguero de la ciudad, pero en 1821 he podido comprobar que la ocupaba el propio Francisco Hinojosa. El padrón de este año aporta el dato ya comentado sobre su condición militar (oficial retirado concretamente), su edad (50 años) y su origen jerezano. No se señala su estado civil, pero sí que vivía «con su familia».

En esta familia no se incluye, sin embargo, Isabel. En ese mismo padrón de 1821 aparece viviendo ya en la casa de la calle San José. Sólo debe llevar en ella unos meses, porque en el padrón de 1820 residía aún en Francos (76). Su cambio de domicilio está relacionado, indudablemente, con el regreso a Jerez de Francisco Hinojosa, casi con toda seguridad su hermano (77). Y lo que también parece evidente es que no existían buenas relaciones entre ambos. De lo contrario, no se explica la marcha de Isabel a otra residencia, pues la mansión familiar era una casa-palacio perfectamente preparada para albergar a un buen número de personas. De hecho, la finca donde se instala, bastante más modesta, está ocupada según las fechas por una o dos familias más, entre ellas, la del propietario de la misma. Tampoco tiene explicación que Isabel no vuelva a ocupar la casa de Francos cuando Francisco se marcha nuevamente, hecho que se produce antes de 1824, año en el que, como se ha visto, hay un nuevo inquilino extraño a los Hinojosa (78). Cabe suponer que Francisco prefería obtener una sustanciosa renta por el alquiler de la casa, aún cuando, presumiblemente, tuviera que pagar el arrendamiento de la que ocupaba Isabel (79). Y también cabe conjeturar que tendría una residencia estable en otro lugar, un lugar que quizás abandonó por los acontecimientos políticos del Trienio, al que volvió con intenciones de mantenerse definitivamente $o$, al menos, por una larga temporada.

A partir de estos datos objetivos podemos intuir que Isabel, bien desde la muerte de su padre o bien desde antes, vivía en otra población con alguno de sus hermanos o con otros parientes. Esta otra población pudo ser en algún momento Córdoba pero posteriormente debió vivir en Cádiz, ya que en esta ciudad nació Agustín (80), el niño que vive con ella en Jerez y que tiene todas las trazas de ser 
su hijo. Puede deducirse, pues, que en uno de estos domicilios, o quizás en otro ignorado, Isabel quedó embarazada sin posibilidades de contraer matrimonio con el padre de su hijo. Cuando este hijo nació la familia con la que vivía (¿Francisco, quizás?) la envío de nuevo a Jerez, con el fruto de su deshonor y con una criada por única compañía. Las relaciones entre Isabel y sus allegados debieron deteriorarse a raíz de este acontecimiento.

La incorporación de Dominga al servicio de Isabel se produjo en algún momento entre 1813 y 1818 , probablemente a causa de la muerte de su criada Catalina. Dominga sería enviada por los familiares de Isabel desde Cádiz o desde El Puerto, donde la situaba el padrón de 1819 (81). Lo que no sé es si Dominga permaneció con esta mujer hasta el fin de sus días o si, por alguna razón, la relación entre ambas se truncó. Desgraciadamente no he encontrado a Isabel Hinojosa en los padrones de 1826,1827 y 1828 . Ni en la casa de la calle San José, donde sigue viviendo el mismo propietario del inmueble junto a algún nuevo vecino, ni en la casa familiar de la calle Francos, en la que cada año hay un inquilino distinto, siempre de nivel social elevado. Sin embargo, en la partida de defunción que ha dado lugar a toda esta historia se precisa que la finada vivía en San José, lo que coincide con el último domicilio conocido de Isabel y de la propia Dominga. Para confirmar que no residía en una casa diferente he buscado en toda la calle y en las vías de los alrededores y tampoco la he localizado. Por ello, sólo hay dos explicaciones posibles. Que los padrones no las registren por su condición femenina, de la misma manera que no las recogía el de 1820 y sin embargo existe certeza de que seguían viviendo en la casa de Francos. De hecho, son padrones confeccionados para el servicio de milicias, y con una estructura nueva de división por clases que permite la exclusión de determinados sectores poblacionales que no interesan ni por su edad, ni por su sexo ni por su nivel económico. Otra posibilidad es que Isabel se hubiese trasladado a otro lugar sin llevar consigo a Dominga e, incluso, que hubiese muerto. En tal caso, Dominga no figuraría en los padrones porque carecía de cualquier utilidad estadística debido a su anciana edad y a sus escasos o nulos recursos económicos. De cualquiera de las maneras, su final debió ser triste. El acta de defunción señala al margen: «negra y pobre». Y también indica que «fue sepultada en el cementerio general con entierro que se le hizo por Dios». Ambos testimonios son bastante elocuentes para apreciar que veintiún años de esclavitud y treinta de servidumbre concluyeron en una muerte en soledad y en un entierro de caridad. Si, además, seguía viviendo con Isabel, su fin resulta aún más triste.

Sucky, María Josefa y Dominga. Tres identidades para tres estapas de una misma vida. La desconocida como Sucky hasta los diecisiete años, la de esclava en Cádiz como María Josefa y la de liberta, que finaliza en Jerez, como Dominga. Tres etapas bien diferentes y la vez muy semejantes. Una trayectoria lineal con tres nudos en su recorrido.

La vida de Dominga ejemplifica la casi anónima existencia de otros muchos esclavos. No debió ser una vida especial. Ni por venturosa ni por desgraciada. Las diferentes situaciones a las que se tuvo que enfrentar y adaptar no tienen 
nada de excepcional para un ser humano en sus circunstancias. La historiografía sobre el tema coincide en que los esclavos, en general, no debieron vivir mal. Entiendo que es un axioma que adquiere su sentido si se establece una comparación con las clases más humildes de la época. Pero, ¿qué es vivir bien?: ¿tener comida y techo asegurado?, ¿no ser objeto de malos tratos? Desde luego, gozar de esas tres prebendas no está nada mal. No obstante, si el ser humano se distingue de los restantes seres vivos es porque ha buscado y ha necesitado siempre algo más que cubrir las necesidades primarias. Y la vida privada de libertad, la dependencia absoluta de otros, no permite vivir como un ser humano, todo lo más como un animal afortunado. ¿Es grato acaso para alguien el desarraigo de los suyos, el traslado arbitrario a tierras lejanas y extrañas, la exposición y observación pública cual si estuviera en una feria de ganado, ser vendido y quizás por menos valor del que se paga por cualquier animal, pasar a depender de un señor que te cambia el nombre y te impone una religión, que quizás también te impone relaciones sexuales, que no te remunera el trabajo que realizas para él, y que probablemente nunca te tendrá el más mínimo aprecio y por eso te vuelve a vender? $\_$Es agradable cambiar constantemente de amos y no tener posibilidad siquiera de hacerte querer por esos continuos cambios? Y no hablemos de la vida personal, porque en la mayoría de los casos no existe. No tienes derecho a amar a nadie, y si lo haces no está asegurado el consentimiento que te permita disfrutarlo; tampoco está claro que puedas mantener a tus hijos contigo: no son tuyos, pertenecen también a tu dueño. Pese a todo, puedes tener la suerte de que algún propietario benevolente, o sólo previsor con su economía, decida graciosamente concederte la libertad. La ansiada y deseada libertad. No es tan difícil. Les ocurre a muchos. Entonces sí que eres un esclavo afortunado. Eso sí, difícilmente podrás regresar con los tuyos. Ha pasado demasiado tiempo. Además, ¿a dónde volver?, ¿quiénes son los tuyos? Tal vez no lo recuerdes o no lo supiste nunca. En todo caso ¿con qué dinero regresar? Pero no hay problema, quizás durante los años de esclavitud hayas hecho conocimientos que te puedan dar o conseguir un trabajo. Seguirás haciendo lo mismo, lo que tú tan bien sabes hacer: servir. Sólo que ahora pende sobre tí la inseguridad laboral. El avance de la edad es imparable y si no consigues que te tengan un poco de afecto te puedes ver solo y en la calle.. Pero no es probable; sería demasiada mala suerte.

Ésta es sin duda una reflexión ácida. Pero también es un razonamiento muy cercano a la realidad. Querría, de todos modos, concluir este trabajo con un pensamiento más positivo. Como apunta la frase referente a Sucre con la que he querido recordar a José Luis (ya que él la señaló en la novela de García Márquez que le presté allá por 1990), la mayor victoria es estar vivo y quizás también lo fue en el caso de esta esclava y de los esclavos anónimos representados en ella. Quizás su vida no fue lo desdichada que a mí me puede parecer, o quizás, al menos, entre tanta desdicha ella supo extraer razones poderosas para soportarla e incluso disfrutarla en sus momentos más leves. Al fin y al cabo eso hacemos todos en nuestras más o menos fáciles existencias de finales del siglo XX. 


\section{NOTAS.}

(1) W.D. PHILLIPS, Jr., Historia de la esclavitud en España, Madrid, Playor, 1990 , pág. 9.

(2) En el estudio de W.D. Phillips anteriormente citado podemos encontrar un completo e interesante recorrido por la historia de esta institución en España y en las colonias americanas desde los primeros tiempos hasta su total decadencia y fin. La síntesis que incluimos a continuación está extraída de él.

(3) Ibídem, pág. 99.

(4) El decreto principal que puso fin a la esclavitud en España fue una real ordenanza de marzo de 1836 que prohibía traer esclavos de las colonias de ultramar. Para esas fechas, las únicas colonias americanas eran Puerto Rico y Cuba. En estos territorios la esclavitud fue abolida en 1873 y 1880 respectivamente, aunque en Cuba los esclavos liberados en esa fecha aún tuvieron que trabajar unos años para sus antiguos amos como compensación por el precio de la libertad. Vid. Ibidem, pp. 251-252.

(5) Aunque no se ha mencionado anteriormente, este tipo de esclavitud también se dio en la América colonial, y sin duda con una mayor intensidad y proyección que en España. No era otro que el modelo practicado por los Estados cristianos medievales del Mediterráneo y, en gran medida, por la civilización islámica, que había dejado profundas huellas en los estados ibéricos. Precisamente el reflujo de esas costumbres desde las colonias debió influir enormemente en el mantenimiento del sistema esclavista en las zonas españolas directamente vinculadas con ellas.

(6) Desde el artículo pionero de DOMINGUEZ ORTIZ a principios de los años cincuenta ( La esclavitud en Castilla durante la Edad Modema», Estudios de Historia Social de España, 2, 1952, pp. 369-428), el estudio de esta institución en España en ese período de su historia, que es también el de su decadencia y final, ha conocido un importante desarrollo. El testigo propuesto por el profesor sevillano fue recogido en los primeros años sesenta por VICENTA CORTES, que investigó el reino de Valencia, una de las principales zonas esclavistas de la península (La esclavitud en Valencia durante el reinado de los Reyes Católicos. Valencia, 1964). Y en los primeros setenta, ALFONSO FRANCO se lanzó al estudio del otro principal mercado de esclavos, el reino de Sevilla (La esclavitud en Sevilla y su tierra a fines de la Edad Media, Sevilla, 1979). Desde entonces hasta hoy las investigaciones sobre este tema han proliferado y en la actualidad contamos con un horizonte bastante alentador, aunque quedan numerosa slagunas por cubrir tanto a nivel cronológico como espacial. A nivel cronológico, los siglos XVII y XVIII, que evidentemente han sido escasamente estudiados por la menor incidencia de la esclavitud frente a los siglos XV y XVI. 
Y a nivel espacial, amplias zonas peninsulares consideradas parcial o totalmente extrañas al fenómeno, como Cataluña, Castilla o la cornisa cantábrica, y lugares puntuales de entornos tradicionalmente esclavistas aún no investigados o estudiados someramente como Cádiz, Extremadura o Baleares. Un actualizado comentario de la bibliografía existente se puede ver en el libro que ALFONSO FRANCO publicó hace unos años bajo el título Esclavitud en Andalucía 1450. 1550 (Granada, Universidad de Granada, 1992, pp. 13-18). En él ofrece un panorama completo de la institución en esta región en el tránsito de la Edad Media a la Moderna que es una síntesis de sus propias investigaciones sobre el tema y del material historiográfico surgido con posterioridad a ellas.

(7) José Luis CORTES LOPEZ: La esclavitud negra en la España peninsular del siglo XVI. Salamanca, Ediciones Universidad de Salamanca, 1989, pp. 1824. El otro estudio mencionado se titula: Los orígenes de la esclavitud negra en España. Madrid, Mundo Negro y Ediciones Universidad de Salamanca, 1986.

(8) En su trabajo sobre la esclavitud sevillana, Alfonso Franco expone con amplitud de detalles las razones que explican esta numerosa presencia esclava en las ciudades andaluzas. Vid. La esclavitud en Sevilla y su tierra...op. cit., pp. 86 y 73-103.

(9) Realmente, el caso de Cádiz se desconoce con exactitud puesto que no se ha estudiado en profundidad. No obstante, la impresión es clara hasta el siglo XVII por los trabajos parciales hasta ahora realizados: HIPOLITO SANCHO DE SOPRANIS, La cofradía de los morenos de Cádiz, Tánger, Publicaciones del Instituto General Franco para la Investigación Hispano-Arabe, 1940, y Las cofradias de morenos en Cádiz, Madrid, Instituto de Estudios Africanos, CSIC, 1958; JOSE SANCHEZ HERRERO, «Cádiz, plaza del comercio de esclavos a finales del siglo XV", en Gades, 5, Cádiz, 1980, pp. 77-83; MANUEL BUSTOS RODRIGUEZ, Cádiz: los siglos decisivos (XVI-XVII-XVIII), Madrid, Sílex, 1990; ISIDORO PORQUICHO MOYA, Cádiz, población y sociedad, 1597 1650, Cádiz, Diputación Provincial de Cádiz, 1994; ARTURO MORGADO Y DOLORES NUÑEZ, «La esclavitud en Cádiz en la segunda mitad del siglo XVII», en I Coloquio de Historias Locales, Cádiz, 1989 (Actas no publicadas). En el caso del siglo XVIII, las referencias son casi nulas. El estudio de BIBIANO TORRES RAMIREZ: La Compañía Gaditana de Negros (Sevilla, Escuela de Estudios Hispanoamericanos de Sevilla, 1973) nos hace entrever, al menos, las vinculaciones que la ciudad y sus poderes fácticos tenían con la trata negrera en América. Por lo demás, las únicas alusiones al tema son las de RAMON SOLIS en sus libros El Cádiz de las Cortes (Madrid, Sílex, 1987) e Historia del periodismo gaditano, 1800-1850 (Cádiz, Instituto de Estudios Gaditanos, Diputación Provincial de Cádiz, 1971), aunque ambos se sitúan en los comienzos del siglo XIX. En esta fecha la esclavitud es aún una realidad social de la ciudad, por supuesto mucho menos relevante que en siglos anteriores y ligada fundamentalmente a personas que han vivido en América. Sobre todo son frecuentes las manumisiones, lo que indica al mismo tiempo su trascendencia en las décadas precedentes. Literalmente, R. Solís afirma que los esclavos y los 
libertos en Cádiz, «en el siglo XVIII eran numerosos» (El Câdiz de las Cortes, op. cit., pág. 78). Con mucha probabilidad sería así, porque la presencia de esclavos en fechas pretéritas fue, como demuestra el citado estudio de Porquicho Moya (pp. 72-73) de una importancia sorprendente, y la inercia establecida en este tema no debió cambiar de signo de un día para otro, máxime cuando la ciudad estaba más vinculada que antes, incluso, a los territorios coloniales. Sin embargo, no cabe duda de que hace falta una investigación de base que lo confirme.

También las otras ciudades andaluzas más implicadas en la práctica esclavista necesitan estudios que determinen su envergadura en los distintos períodos. Según señala Alfonso Franco en su mencionado estado de la cuestión (vid. nota 6), Málaga era objeto por entonces de una memoria de licenciatura, y Córdoba de una tesis doctoral, si bien ambas publicaciones contaban ya con algún que otro trabajo puntual. Sevilla misma, el mercado de esclavos más importante de toda Europa Occidental junto con Lisboa, está perfectamente estudiada en los años finales del siglo XV y primeros del XVI, pero se desconocen los años y centurias siguientes, aunque, como apunta el mismo autor, ya se están investigando en profundidad los siglos XVI y XVII.

(10) Aunque la argumentación era en parte diferente a la que hacen hoy día los investigadores de la esclavitud, pues no alude en ningún momento al impulso que la institución experimentó en nuestras fronteras a raíz del descubrimiento del Nuevo Mundo y su posterior explotación económica, las conclusiones a las que llega el historiador portuense sobre la actividad esclavista en la provincia gaditana son en esencia las mismas. Textualmente, Hipólito Sancho afirma: «La población de color fue sumamente abundante en la Andalucía Occidental a partir del siglo XV: primero, las entradas en Marruecos, que suministraban cantidad de esclavos de raza negra; después, las expediciones a Guinea, cuya más preciada mercancía era la humana; más tarde, la presencia en los puertos de Sanlúcar, Huelva, sevilla, Cádiz y Puerto de Santa María de mercaderes portugueses y no raramente genoveses, que a este tráfico se dedicaban, y por fin, las grandes hambres que asolaron Marruecos y obligaron a los habitantes de este imperio a deshacerse por poco precio de esclavos que de otra manera perdería, fueron factores que hicieron que los morenos, como se les solía apellidar, fuesen extraordinariamente numerosos en Cádiz, Jerez, Sanlúcar, el Puerto, en suma, en todas las poblaciones de esta punta de Andalucía». Cfr. HIPOLITO SANCHO DE SOPRANIS: La cofradía de los morenos de Cádiz...op. cit., Tánger, 1940, pág. 7.

(11) ANTONIO MORENO OLLERO, Sanlúcar de Barrameda a fines de la Edad Media, Cádiz, 1983, pp. 161-169.

(12) JUAN JOSE IGLESIAS RODRIGUEZ, Una ciudad mercantil en el siglo XVIII: el Puerto de Santa María. Granada, Servicio de Publicaciones de la Universidad de Sevilla, Fundación Municipal de Cultura de El Puerto de Santa María y Muñoz Moya y Montraveta Editores S.A., 1991, pp. 583-595. 
(13) HIPOLITO SANCHO DE SOPRANIS, Las cofradias de morenos en Cádiz, op. cit., Madrid, 1958, pp. 10-11.

(14) ALFONSO FRANCO SILVA, La esclavitud en Sevilla, op. cit., pp. 78, 83, $218,223$.

(15) Es el caso, por ejemplo, de J.L. CORTES LOPEZ, que recoge dicha información en su estudio sobre La esclavitud negra..., op. cit., pág. 90. y de JACQUES HEERS, que también se hace eco de las noticias que Alfonso Franco ofrece de Jerez en su trabajo ya clásico Esclavos y sirvientes en las sociedades mediterráneas durante la Edad Media, Valencia, Edicions Alfons El Magnanim, Institució Valenciana d' estudis i Investigació, 1989, pag. 127.

(16) Vid. M.D. LOZANO SALADO, Jerez a principios del siglo XIX: Urbanismo y propiedad, Jerez, Biblioteca de Urbanismo y Cultura, Ayuntamiento de Jerez, 1992, pp. 157-178.

(17) Curiosamente, aunque lo apunto sólo por la coincidencia anecdótica, el barrio de San Marcos albergaba una calle llamada «de los Negros» que aún hoy mantiene ese nombre, del que Agustín Muñoz comenta que puede provenir «de habitar allí los de color moreno, que tenían una cofradía en Santo Domingo», un convento muy próximo a la collación aunque: situado fuera del recinto amurallado. Vid. AGUSTIN MUÑOZ GOMEZ, Noticia histórica de las calles y plazas de Xerez de la Frontera. Ed. facsímil, Jerez, BUC, Ayuntamiento de Jerez, 1988, pp. 189-190.

(18) Cuatro son los estudios centrados en el siglo XVIII de los que tengo constancia. El ya citado de Juan José Iglesias sobre El Puerto de Santa María (vid. nota 12), otro sobre Trujillo y Cáceres (SANTIAGO ARAGON MATEOS y ROCIO SANCHEZ RUBIO: «La esclavitud en la Alta Extremadura: proceso de auge y decadencia», Norba. Revista de Historia, $\mathrm{n}^{\circ} 7$, Cáceres, 1986, pp. 93 109), un tercero sobre Cartagena (RAFAEL TORRES SANCHEZ, «La esclavitud en Cartagena en los siglos XVII y XVII»», Contrastes, $\mathrm{n}^{\circ} 2$, Murcia, 1986) y una investigación más amplia sobre Murcia (ANTONIO PEÑAFIEL RAMON, Amos y esclavos en la Murcia del Setecientos, Murcia, Real Academia Alfonso X el Sabio, 1992). Tal vez exista algún otro trabajo de esta centuria que ignoro, pero en cualquier caso el siglo XVIII, en materia esclavista, es, como apuntan S. Aragón y R. Sánchez en su mencionado artículo (pag. 93) un gran desconocido.

(19) Cuando recogí esta información los registros parroquiales se encontraban aún en el propio archivo de la parroquia, pero en la actualidad dicha documentación, al igual que la existente en las restantes parroquias y conventos de la diócesis, se encuentra centralizada en el Archivo del Obispado de Jerez (A.D.J.F.). En el caso de los registros bautismales, utilicé los libros 8 (1718- 
1758), 9 (1759-1799) y 10 (1797-1829); en el de los registros matrimoniales los libros 4 (1672-1727) y 5 (1728-1798) y en el de los de defunción, los libros I (1693-1760), 2 (1761-1794) y 3 (1793-1834). No obstante, siempre comencé la búsqueda en 1700, con la excepción de los libros de bautismo, en los que la inicié en 1718.

(20) Treinta y cinco protagonistas directos de las partidas analizadas, y cuatro esclavas como protagonistas indirectas a través de su condición de madres de los bebés bautizados y de los esclavos que contraen matrimonio.

(21) Por ejemplo, las cuatro mujeres mencionadas arriba, madres de las dos niñas bautizadas y de los dos jóvenes casaderos, no aparecen en las actas de defunción y, desde luego, en el período analizado transcurre tiempo de sobra necesario para que se hubiesen producido los fallecimientos.

(22) Los lugares con los que puedo establecer comparaciones son El Puerto de Santa María, la Alta Extremadura (Trujillo y Cáceres conjuntamente) y Murcia capital, pues no he podido acceder al estudio sobre Cartagena también citado en la nota 17. En la investigación portuense se ofrecen dos tipos de información diferentes: una puntual de 1752, procedente de los Libros de Familias del Catastro de Ensenada, y otra general para toda la centuria, extraída de los protocolos notariales a través de un sistema de muestreo. El estudio del siglo XVIII en la Alta Extremadura se basa en un vaciado íntegro de los protocolos de Trujillo y Cáceres, completado en el caso de Cáceres con fuentes parroquiales. Finalmente, la monografía sobre Murcia se asienta también en documentación notarial analizada mediante catas y sondeos.

(23) De los tres estudios referidos, sólo en el de El Puerto se aportan noticias sobre este particular. Noticias numerosas de todo el Setecientos que se pueden resumir, en aras de la concisión y aunque no sea totalmente exacto, en un contingente poblacional aproximado de 16.000 habitantes, al menos durante la segunda mitad de la centuria (J.J. IGLESIAS RODRIGUEZ, op. cit., pp. 45-48). En el caso de Jerez conozco, como en El Puerto, la contestación a la pregunta ${ }^{\circ}$ 21 de las Respuestas Generales del Catastro de Ensenada (7033 vecinos, que multiplicados por el coeficiente 4,5 , generalmente aceptado para la época como tamaño medio familiar, darían un vecindario de 31.649 habitantes) y la población registrada por el Censo de Floridablanca en 1787 (45.506 habitantes). Pero desconozco la población de cada collación, aunque las reducidas dimensiones del barrio de San Marcos me han permitido sin problemas hacer un recuento de sus efectivos, que en 1818 eran 1122. Esta cifra sería algo más elevada durante la segunda mitad del siglo XVIII, pues la población de Jerez experimentó en los primeros años del XIX un descenso considerable, de más de 10.000 habitantes (Vid. M.D. LOZANO, op. cit., pp. 23-27).

(24) 2201 según el Censo de Floridablanca, INSTITUTO NACIONAL DE ESTADISTICA. Censo de 1787 «Floridablanca». Cádiz, Madrid, 1986, pág. 158. 
(25) Los protocolos relacionados con esclavos son muy numerosos en las primeras décadas, pero decaen considerablemente a partir también de 1730. Por otra parte, cuarenta y cuatro de las ochenta escrituras son concesiones de libertad (J.J. IGLESIAS RODRIGUEZ, op. cit., pág. 585). En el caso de Trujillo y Cáceres no se especifica esta información, aunque la progresiva decadencia de la práctica esclavista queda igualmente demostrada por la comparación establecida con el siglo XVI, ya que en él se encontraron ciento cuatro escrituras notariales referentes a esclavos, mientras que en el XVIII sólo catorce (S. ARAGON MATEOS Y R. SANCHEZ RUBIO, loc. cit., pág. 94). En el estudio de Murcia también se aprecia este descenso paulatino de la actividad esclavista, pero no tan claramente como en los restantes casos, pues si bien el número de protocolos encontrados desciende a partir de 1730, los últimos años cuarenta y los cincuenta registran una importante subida, para sí comenzar un descenso continuado en la década de los sesenta. No obstante, Murcia tiene unas características peculiares en este tema, similares a las de su entorno y distintas a las de la España occidental, ya que no se abastece fundamentalmente del mercado negro, sino del islámico resultante de la lucha cristiano-musulmana, poor lo que las alzas y bajas en las compraventas de esclavos deben estar relaiconadas sin duda con las disponibilidades coyunturales de ese mercado (A. PEÑAFIEL RAMON, op. cit., pp. 39-83).

(26) Quizás esté en relación con esta práctica el hecho de que los esclavos de las partidas de bautismo y matrimonio no aparezcan también las de defunción (por supuesto, media en todos los casos el tiempo suficiente o más que suficiente para que se produjeran los fallecimientos). Aunque también estas ausencias a la cita ineludible se pueden explicar por la obtención de la libertad y el cambio consecuente de domicilio. De este tema, no obstante, hablaremos más adelante.

(27) J.J. IGLESIAS RODRIGUEZ, op. cit., pp. 590-591.

(28) Por supuesto, también se debe atribuir al celo y preocupación del párroco que redacta la partida, pero aún así este aspecto estaría muy condicionado por los usos y costumbres habituales.

(29) La utilización del sustantivo o adjetivo moreno como sustituto eufemístico de negro estaba muy extendida en épocas pasadas. Así la aplican, por ejemplo, Agustín Muñoz al explicar el origen de la jerezana calle de los Negros o Hipólito Sancho en sus trabajos sobre las cofradías creadas por los libertos en algunas poblaciones gaditanas durante los siglos XV y XVI (Vid. respectivamente notas 17 y 9). Isidoro Porquicho se pronuncia sin dudas sobre el carácter paliativo de esta expresión (op. cit., pp. 77, 127 y 140). Y Ramón Solís comenta el empleo de dicha palabra en los padrones municipales de Cádiz para hacer referencia a los habitantes negros: «en el padrón de 1813, no es difícil encontrar al lado de algunos vecinos la observación de «moreno de color», o simplemente «de color» (El Cádiz de las Cortes, op. cit., pág. 78). 
(30) Vid. A. FRANCO, La esclavitud en Sevilla y su tierra, op. cit., pp. 214-215, y S. ARAGON y R. SANCHEZ, «La esclavitud en la alta Extremadura», loc. cit., pág. 96.

(31) I. PORQUICHO, op. cit., pp. 125 y ss.

(32) S. ARAGON y R. SANCHEZ, loc. cit., pág. 96.

(33) A. FRANCO, La esclavitud en Sevilla y su tierra, op. cit., pág. 216.

(34) ANTONIO DOMINGUEZ ORTIZ, Sociedad y Estado en el siglo XVIII español, Madrid, Ariel, 1981 (reimp.), pág. 338; GONZALO ANES, El Antiguo Régimen: los Borbones, Madrid, Alianza Universidad, 1983 ( $6^{a} \mathrm{ed}$ ), pág. 152; RAMON SOLIS, El Cádiz de las Cortes, op. cit., pág. 77; J.J. IGLESIAS, Una ciudad mercantil, pág. 584 , etcétera.

(35) Vid. por ejemplo, G. ANES, op. cit., pp. 152-153 y J.J. IGLESIAS, op. cit., pág. 584.

(36) A. FRANCO SILVA, Esclavitud en Andalucía, op. cit., pp. 143-190.

(37) S. ARAGON y R. SANCHEZ, «La esclavitud en la alta Extremadura», loc. cit., pp. 100-102.

(38) Aunque no siempre se manifiestan claramente al respecto, entiendo que en estos términos se inscriben los planteamientos de A. Domínguez Ortiz, G. Anes, R. Solís o J.J. Iglesias en sus trabajos ya tantas veces mencionados.

(39) El autor señala que la posesión de esclavos se reparte entre casi todos los oficios de la villa y especialmente entre los del sector terciario y secundario. Vid. A. MORENO, Sanlúcar de Barrameda a fines de la Edad Media, op. cit., pp. $165-167$.

(40) J.J. IGLESIAS, Una ciudad mercantil en el siglo XVIII, op. cit., pp. 584585 .

(41) No sólo lo confirma el artículo sobre la Alta Extremadura de S. Aragón y R. Sánchez. También el estudio de la esclavitud en la Baja Extremadura en el siglo XVII realizado por FERNANDO CORTES CORTES muestra la progresiva reducción de los grupos sociales propietarios (Los esclavos en la Extremadura meridional del siglo XVII, Badajoz, Diputación Provincial de Badajoz, 1987, pp. 131-138).

(42) En esta ciudad, la tipología social de los propietarios de esclavos en el siglo XVIII era más variada, pero la presencia de las clases menos pudientes me parece meramente testimonial. No obstante, Peñafiel interpreta la omisión frecuente de la identificación social o profesional de los propietarios como un 
indicio de su escaso relieve social, lo que sólo creo es posible en los casos que carecen de tratamiento de don. Al menos, eso se infiere de la observación de los datos encontrados, puesto que el autor no da información numérica de la diferente casuística. ANTONIO PEÑAFIEL; Amos y esclavos, op. cit., pp. 3952 y $85-94$.

(43) De casi todos ellos se pueden encontrar referencias en el libro de DIEGO PARADA Y BARRETO: Hombres ilustres de la ciudad de Jerez de la Frontera, precedidos de un resumen histórico de la misma población. Jerez, Imprenta del Guadalete, 1875. Sobre los que no hay noticias, tengo constancia de su mayor o menor grado de nobleza a través de los padrones de habitantes de principios del siglo XIX existentes en el Archivo Municipal de Jerez, documentación que conozco bien por otras investigaciones que estoy realizando.

(44) JAVIER M. DONEZAR, refiriéndose a la provincia de Toledo de mediados del siglo XVIII, señala que en esta categoría se incluían «los pocos hidalgos rurales, los hijos segundones sin título de familias nobiliarias, determinados cargos estatales, individuos dedicados a profesiones liberales y labradores y comerciantes enriquecidos" y la considera un grupo «puente» entre la nobleza y el estado. llano, aunque los dones se vinculaban a las dos clases sociales mencionadas. Además, aclara que no todos los comerciantes, ni los labradores ni los profesionales liberales gozaban de dicho calificativo por el simple hecho de disponer de una situación económica desahogada ni de estudios superiores. El otorgamiento del «don» en el estado llano reconocía no sólo capital sino también capacidad y distinción (Riqueza y propiedad en la Castilla del Antiguo Régimen. La provincia de Toledo en el siglo XVIII, Madrid, Instituto de Estudios Agrarios, Pesqueros y Alimentarios, 1984, pág. 298).

(45) GONZALO ANES, op. cit., pág. 152. De todas formas, como señala ALFONSOFRANCO, las ordenanzas gremiales prohibían el ingreso en sus filas a las personas de color, pero no el trabajo del esclavo como tal (Esclavitud en Andalucía, op. cit., pág. 137). Y de ello se deduce que los verdaderos afectados por dichas trabas eran los libertos.

(46) J.J. IGLESIAS, op. cit., pp. 584-585; A. PEÑAFIEL, op. cit., pp. 91-92; S. RAGAON y R. SANCHEZ, op. cit., pp. 101 y ss.

(47) En los estudios de El Puerto y de Trujillo y Cáceres citados en la nota anterior aparecen respectivamente cinco eclesiásticos entre los propietarios de esclavos, aunque los correspondientes autores no aclaran sus diferentes rangos en la escala religiosa. En el estudio de Murcia, A. Peñafiel comenta una mayor presencia de los «simples presbíteros» entre los compradores y vendedores de esclavos.

(48) R. Solís para Cádiz, J.J. Iglesias para El Puerto y S. Aragón y R. Sánchez para la Alta Extremadura. Vid. R. SOLIS, El Cádiz de las Cortes, op. cit., pág. 
77; J.J. IGLESIAS, op. cit., pp. 584-585; S. ARAGON y R. SANCHEZ, op. cit., pág. 96.

(49) La información que tengo de él proviene fundamentalmente de los padrones de habitantes de 1792, 1815 y 1818 existentes en el Archivo Municipal de Jerez (A.M.J.F.). De 1803 y de los años inmediatamante anteriores y posteriores no hay ninguno. Aparte, tengo conocimiento de sus bienes y actividades comerciales por el Apeo de la Riqueza General del Reino realizado en 18181819 (Archivo Histórico Provincial de Cádiz, Sección Gobierno Civil, Fomento, Cajas 247, 248 y 249).

(50) La lectura del libro de Parada y Barreto ya mencionado (Hombres ilustres...) deja claro este particular. La carrera militar era una práctica común en la nobleza española de la época e igualmente habitual era la prestación de servicios en los territorios coloniales. Casi todos los militares jerezanos del Setecientos verificaron empresas de diferente calado en el continente americano.

(51) RAMON SOLIS en su obra sobre el Cádiz de las Cortes comenta lo siguiente «Es de creer que los esclavos se adquieran muy jóvenes, el hecho de que suelan coincidir en edad con niños de la familia a la que sirven, supone que su misión era principalmente la de ser compañeros de juegos de éstos, o camareras de la señora o de sus hijas. En la mayor parte de los casos se les concedía la libertad al llegar a cierta edad» (El Cádiz de las Cortes, op. cit., pp. 77-78).

(52) J.J. IGLESIAS, op. cit., pág. 585.

(53) Reproduzco aquí parte de uno de ellos, publicado el día 30 de junio de 1822 y dedicado a la señora doña Agustina Imbrechts de Retortillo:

¿Qué estoy mirando? El Numen del decoro/de la clemencia la adorable Diosa/la dulce madre, la mejor esposa/y de virtudes celestial tesoro/;Oh musas; Genios del castillo coro/que la visteis sensible y generosa/a un triste dar su libertad dichosa/pulsad por ella vuestras liras de oro.

(R. SOLIS, Historia del periodismo gaditano, op. cit., pp. 153-155).

(54) A.D.J.F., Parroquia de San Marcos, Libros de Defunción, 3, fol. 163.

(55) Archivo Histórico Provincial de Cádiz (A.H.P.C.), Not. 10, libro 1888, pág. 2.

(56) Esta edad no cuadra exactamente con la de la muerte, aunque haya una diferencia nimia (de dos años), motivada, sin duda, por la falta de certeza en la que tenía cuando llegó a España. De todas formas, el reflejo documental de la 
edad es una cuestión que presenta, como tendremos ocasión de ver, muy poco rigor en estos tiempos.

(57) A.H.P.C., Not. 24, libro 5561, pág. 532.

(58) Con la excepción de la referencia sobre la dentadura, que se ignora, y la alusión a las marcas de viruelas, que se endurece sustituyendo la expresión «pecosa» por «hoyos» o «señales». También, en otras ocasiones, se anota que es «de color negro» en lugar de «cocho».

(59) Este señor aparece en la relación de individuos que se inscribieron en el Consulado de Cádiz para el comercio con América. La misma fuente indica que era natural de Ceuta y que se matriculó en el año 1774. Vid. JULIAN RUIZ RIVERA, El Consulado de Cádiz: matrícula de comerciantes (1730-1823), Cádiz, Diputación Provincial de Cádiz, 1988, pág. 139.

(60) La primera escritura ya comentada -que no es de compraventa, pues dicho instrumento debió realizarse en Londres, sino de declaración y resguardo del encargo de compra realizado- especifica que «no se le conoce qué religión profesa». Este dato confirma el posterior bautizo, pero siembra dudas sobre su origen último, que, por el color de su piel, había imaginado no muy lejano.

(61) A.H.P.C., Not. 17, libro 3848, pp. 411-413.

(62) A.H.P.C., Not. 17, Libro 3849, pp. 241-243. El dato sobre su procedencia proviene de la matrícula de comerciantes' anteriormente citada, en la que se registró el mismo año de 1784 (J. RUIZ RIVERA, op. cit., pág. 181).

(63) Estas dos operaciones las conozco por la venta posterior que realiza Doña Manuela Danglada al último propietario de María Josefa. Sin embargo, a pesar de que en la escritura se dan las referencias exactas de las fechas y notarios ante los que se hicieron los pertinentes documentos protocolares, no he logrado encontrarlos en los respectivos legajos (y la búsqueda ha sido exhaustiva por si existía algún error en las fechas). A.H.P.C., Not. 16, libros 3798 y 3800.

(64) Y esposa de don Bernabé Elías, otro comerciante matriculado en la carrera de Indias desde 1776, originario de La Rioja (JULIAN RUIZ RIVERA, op. cit., pág. 155).

(65) A.H.P.C., Not. 10, lib. 1885, pp. 574-578.

(66) El precio que adquiere el esclavo en venta está condicionado fundamentalmente por el sexo y la edad y en menor medida por otros aspectos como la salud, la fortaleza física y las habilidades laborales. En María Josefa hay que presumir una buena combinación de todos estos factores pues el paso del tiempo no hizo descender su valor (y sus diversas transacciones se produjeron a $\operatorname{los} 17,23,24,32,33$ y 34 años respectivamente). La consideración de que es un 
importe elevado se aprecia si lo comparamos con los 1760 reales pagados en 1760 en El Puerto por una esclava mulata de 28 años. Según Juan José Iglesias, éste es el precio más alto alcanzado por una esclava en esas fechas (J.J. IGLESIAS, op. cit., pág. 588).

(67) Se señala que es comerciante en la carta de libertad de la esclava y consta igualmente en la matrícula estudiada por Julián Ruiz (Ibidem, pág. 148).

(68) Ignoro si la trayectoria de esta esclava, que conoce seis compraventas antes de obtener la libertad, es excepcional en el período y entorno geográfico estudiado. Probablemente no. En la investigación de Alfonso Franco sobre Sevilla a finales de la Edad Media se refleja que no era extraño servir a más de un dueño, pero lo más que constata son casos de tres (La esclavitud en Sevilla y su tierra, op. cit., pp. 227-228). Sin embargo, en el estudio de la Alta Extremadura de S. Aragón y R. Sánchez se afirma que «era normal conocer tres $\mathrm{y}$ hasta cuatro amos, o incluso más», y que «dicho trasiego parece mayor en el siglo XVIII, aunque también es visible en el XVI» («La esclavitud en la Alta Extremadura», loc. cit., pág. 99).

(69) Por el contrario, se mueve dentro de los cánones más esterotipados de la fórmula notarial: «...por el presente instrumento otorgo que doy graciosamente libertad a la susodicha para que desde este día en adelante pueda hacer lo mismo que una persona libre, como si no hubiera estado sujeta a servidumbre, tratando y contratando, y usando del caudal que adquiriese, haciendo todos los instrumentos que tenga por conveniente, siguiendo cualesquiera litigios, según y cómo más bien le parezca, pues a dicho fin hago a favor de la referida María Josefa la más bastante carta de libertad que a su derecho y seguridad convenga, con cuantas claúsulas, requisitos y solemnidades para su estabilidad y firmeza se requieran» (A.H.P.C., Not. 10, lib. 1888, pág. 2).

(70) A.M.J.F., Padrón Vecinal, 1818-1819. Padrón Vecinal de la Comisaría de San Marcos para reemplazo del ejército concluido el 12 de enero de 1818 y Padrón vecinal de la Comisaría de San Marcos (Quintas) concluido en mayo de 1819. El comentario sobre la edad se debe a la incoherencia de este dato en los diferentes patrones donde la he localizado. Así, en 1813 tiene 34 años; en 1818, 32 , los mismos que en 1819; en 1821, 35; y en 1824, tan sólo 30 .

(71) PORQUICHO, I., op. cit., pp. 75-76.

(72) D. PARADA Y BARRETO, Hombres ilustres de la ciudad de Jerez, op. cit., pág. 224.

(73) A través de padrones municipales de las dos fechas citadas y de otros situados entre ambos correspondientes a los años 1804, 1806, 1813, 1818, 1819, $1820,1821,1824,1826$ y 1827 . Todos ellos recogidos en el Archivo Municipal de Jerez. 
(74) Ignoro de cuántos miembros se componía el núcleo principal de los Hinojosa. Ya he apuntado la posibilidad de que José Hinojosa fuera hijo de Sgustín y la casi certeza de que también era su hija Isabel. El tercer integrante identificado se llama Francisco y debía ser el hijo primogénito de Agustín, su sucesor al frente de la familia, pues es él quien aparece como propietario de la casa de Francos en los padrones de años sucesivos. Francisco era militar, así que debía tener destino en otra plaza, lo que explica su ausencia en Jerez.

(75) Agregado: el que, sin ser pariente del dueño de la casa, vive en ella a cargo de él.

(76) Es una deducción, pero no hay dudas al respecto. El padrón de 1820 es, en realidad, una lista de varones entre 18 y 50 años, de manera que la casa de Francos, 85 se salta porque ninguno de sus vecinos reúne las dichas características.

(77) No sólo todas las circunstancias familiares apuntan esta idea. También las edades respectivas coinciden. Si Isabel no se hubiera quitado años respecto a la edad de 1813, en 1824 tendría 45.

(78) Se trata de un cambio de domicilio y no de un fallecimiento porque la casa continúa estando a su nombre en los años sucesivos.

(79) Aunque a ella se le califica en los padrones de 1818 y 1819 como «hacendada», no me consta que tuviera patrimonio alguno en Jerez, aunque tal vez lo poseyera en algún otro lugar. De todos modos, la expresión hacendado/a no se utiliza sólo en los que tienen bienes raíces sino también genéricamente para resaltar una posición desahogada.

(80) Este dato se consigna en el padrón de 1824.

(81) Entre los Hinojosa no debía ser extraña la tenencia de esclavos. En los registros parroquiales analizados previamente también aparecía un miembro de esta familia, domiciliado igualmente en la casa de la calle Francos, como propietario de un esclavo fallecido en 1728. 